\title{
Treatment for anxiety using spiritual emotional freedom technique
}

\author{
Rima Pratiwi Fadli ${ }^{1}$, Yola Eka Putri ${ }^{1}$, Berru Amalianita ${ }^{1}$, Nilma Zola $^{1}$, Ifdil Ifdil ${ }^{2 *}$ \\ ${ }^{1}$ Indonesian Institute for Counseling Education and Therapy, Indonesia \\ ${ }^{2}$ Universitas Negeri Padang, Indonesia
}

\begin{tabular}{l} 
Article Info \\
\hline Article history: \\
Received Jan $17^{\text {th }}, 2020$ \\
Revised Feb $26^{\text {th }}, 2020$ \\
Accepted Mar $12^{\text {th }}, 2020$ \\
\hline
\end{tabular}

\section{Keyword:}

SEFT

Anxiety

DASS

\begin{abstract}
This study aims to describe SEFT and treatment in the treatment of anxiety. This study used rapport cases on three clients. The research instrument used is rapport Client Case, observation and depression, Anxiety, and Stress Scale. The data obtained were analyzed by T-Test Statistic Nonparametric Wilcoxon Signed-Rank Test. The findings from the study showed that before treatment, the level of anxiety at very heavy levels and after the treatment became mild and normal. Based on T-test results found that there is a significant difference in anxiety level of clients before and after treatment. This means SEFT is effective for reducing client anxiety.
\end{abstract}

(C) 2020 The Authors. Published by Redwhitepress.

This is an open access article under the CC BY-NC-SA license (https://creativecommons.org/licenses/by-nc-sa/4.0/

\section{Corresponding Author:}

Ifdil Ifdil,

Universitas Negeri Padang, Indonesia

Email: ifdil@konselor.org

\section{Introduction}

Anxiety can have a positive and negative impact of the individual (Juliantine, 2012). The condition of anxiety can affect the individual's development. Anxiety refers to the state of mental state (Barlow, 2002), response to specific situations (Hazlett-Stevens, 2008), personality traits (Kearney, 2006), causes of behavior, and psychiatric disorders (Luciani, 2002). The disturbance can come from the individual's environment (Prabowo \& Sihombing, 2012). According to Freud in (P Andri, 2007) explains that anxiety occurs because of the unfolding of the libido of the individual. Furthermore, Otto Rank in (P Andri, 2007) also explained that the traumatic experience was the beginning that can bring anxiety. Freud divided the anxiety into three parts namely anxiety, neurotic anxiety, and moral anxiety (Budiantoro, 2015).

Anxiety has been several triggers including stress, life problems and feelings of anxiety (Sanders \& Wills, 2002). According to Santrock in (Yudha, n.d.) anxiety is a feeling of fear and dismay that is unpleasant and unclear. As for the factors of occurrence of anxiety, many come from the self, as described in the results of research (Sari Oktaviani Desmawati, Ardi, Havid, 2013) which shows anxiety occurs because of negative perceptions of the individual related to something. Danielle (2007: 45) found that in the phenomenon of hysteria, the most frequently encountered aspects of psychology are the emotional distress of fear, which is always accompanied by an inner emotional anxiety (Mohammad, 2014). Emotional disturbance in the form of anxiety occurs in many communities and is often associated with mental illness (Saari, 2015). Furthermore, the phenomenon of anxiety also occurs in adult groups such as mother and father (child Takom, Bullare, \& Nawi, 2016). 
As for the world of education, the phenomenon of anxiety has also entered the field aspects of the lesson. As the findings from (Juneman Wahyu; Setiani, Yeni, 2013) that students tend to experience anxiety that leads to academic procrastination among students. The findings are also supported by findings (Padmadewi, 1998) that anxiety often occurs among students during the learning process. In the world of health is also often the case of anxiety, especially to patients (-Shobirun, -, Arwani, 2011). This anxiety phenomenon is also common among caesarean delivery mothers who tend to have anxiety to breastfeed. So it requires counseling to overcome the misconceptions associated with a caesarean section to give birth to her baby. (H. O. Shaibu; J. E., Imhonde; Handayani, Lina, 2012).

Anxiety is generally caused by internal and external factors. The anxiety caused by factors related to the object is raised through a phobia. Furthermore, neurotic anxiety (neurotic anxiety) tends not to be related to external factors. The self-defense mechanisms that individuals emerge often come from anxiety. This selfdefense mechanism can sometimes damage the individual. This is so in accordance with the results of research (Muarifah, 2012) that there is a positive relationship between anxiety with the emergence of aggressiveness.

Based on the above description can be seen that the phenomenon of anxiety occurs in various circles and age in society. Therefore, to handle the phenomenon of anxiety is necessary to do psychological treatment. Treatment given to handle anxiety client one of them is by using SEFT (Spiritual Emotional Freedom Technique). The Spiritual Emotional Freedom Technique (SEFT) is one of the several methods developed to help clients overcome their problems (Mulyo, 2007). The SEFT technique is developed with customized individual properties and is designed to meet the spiritual side attached to everyone. SEFT underlines that humans are primitive creatures that embrace everyday experiences. Furthermore, based on the results of research (Aulianita \& Sudarmiati, 2015) showed that the use of SEFT techniques in tackling the anxiety of women found that there is the influence of SEFT in dealing with anxiety. The findings are also supported by research (Yunita, Darminto, \& Si, 2013) that there are differences in students' anxiety levels after being given the SEFT technique. Based on this case it can be concluded that the use of SEFT technique can be done to handle anxiety. The purpose of the research above is to describe the anxiety level of respondent's research and describe the change of anxiety level of respondents before being given treatment using SEFT technique.

\section{Method}

This research uses a single subject research (SSR) method with three research subjects. Single subject research is a research that examines or observes the same object continuously where the analysis is based upon the use of lines in the graph, die horizontal line for observation of treatment and vertical against behavior (Maturidi, 2014) \& (Creswell, 2013). The research instrument used using DASS model measurement scale. The data obtained were analyzed using percentage technique.

\section{Results and Discussions}

Based on the research results found the following data: 1) Pre-Test, based on the above findings can be shown that the results before treatment showed that the levels of anxiety of respondents generally are in very heavy categories. The third respondent had higher levels of anxiety than the other respondents. The findings indicate that the level of client anxiety is at a very unfavorable stage psychologically; 2) Post-Test, based on the above findings can be shown that the results after treatment using shows that the level of anxiety respondents generally tends to be mild. The first and second respondents had anxiety levels in the light category. These findings indicate that after the treatment using SEFT method found a decrease in the level of client anxiety menadiol mild and normal.

Table 1. Test Statistic Nonparametric Wilcoxon Signed-Rank Test

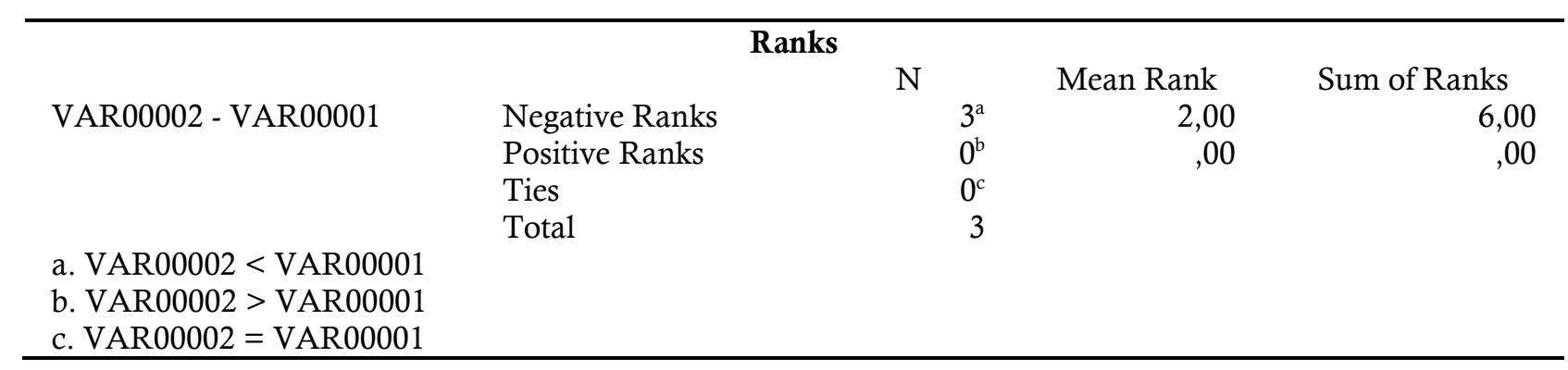




\section{Test Statistics $^{\mathrm{a}}$}

\section{VAR00002 - VAR00001}

Z

Asymp. Sig. (2-tailed)

a. Wilcoxon Signed Ranks Test

b. Based on positive ranks.

Based on the table 1 findings can be explained that the value of Negative Rank is $3 a$, it means that the decrease in the level of anxiety before and after treatment is given. Therefore it can be concluded that the appropriate treatment is used to lower the level of anxiety. Based on the above findings can be explained that the level of anxiety of respondents to decline after treatment. This means that the SEFT method used for effective clients is used to reduce anxiety levels. This is in line with the research findings (Rofacky \& Aini, 2015) in which there are differences after the pre-test and post-test results after the use of the SEFT method. The findings are also supported by research results (Ardtiyani, 2014) that the SEFT method is effectively used for treatment.

\section{Understanding Anxiety}

Anxiety is an anxiety that occurs due to fear of a threatening danger in the real world (Setiawan, 2015). Anxiety (anxiety) is a normal reaction in a situation that greatly depresses a person's life and lasts not long (Ramaiah, 2003). Anxiety often appears on its own and joins other symptoms. Anxiety arises from the reaction of physiological and psychological processes in the human body. Anxiety disorders are divided into two, namely phobia and anxiety state disorder (Yustinus Semiun, 2006). (Astuti, 2010) It, furthermore, explains that anxiety is one form of individual emotion concerning a sense of being threatened by something, usually with a less obvious threat object.

Furthermore, (Kuraesin, 2009) explains that anxiety is a natural distress that is indicated by fear, or a deep and sustained worry. However, no disturbance, in reality, personality does not crack and sometimes behavior is interrupted within normal limits. Homeopathy in (Ramaiah, 2003) also explains that anxiety is the result of uncomfortable thoughts reacting to situations that seem negative to individuals but not openly threatening. Based on the above explanation can be concluded that anxiety (anxiety) is physiological and psychological reactions that cause a conscious disorder that is characterized by feelings of fear and excessive and continuous worries so that individuals consider such a threat to himself.

\section{Factors Causing Anxiety Occurrence}

According to (Ramaiah, 2003) there are several factors that cause anxiety such as environment, suppressed feelings and physical causes that may cause anxiety. Next Ayurveda in (Ramaiah, 2003) the clinical sign of anxiety (anxiety) is fear, loss of confidence in decision making, shaking hands or chills, heart palpitations or awareness of heart rate. The factors causing the anxiety of the environmental aspects of the condition of physical growth and mindset; family and social problematic; developmental problems; crisis, traumatic, collision experienced by individuals in their lives; guilt and fear of punishment; disagreement between the motives of needs and inclinations; and weak feelings (Taufiq, 2007).

\section{Anxiety levels}

Townsend in (Astuti, 2010) explains there are several levels of anxiety (die anxiety). 1) Mild anxiety, this anxiety relates to the tension in everyday life and causes the individual to become alert and increase his perception. The manifestations that appear at this level are fatigue, irritability, increased perception, high awareness, able to learn, increased motivation, and appropriate behavior situations; 2) Medium anxiety, this anxiety allows one to focus on an important issue and override the other so that a person experiences selective attention, but can do something pointed. Manifestations that occur at this level, namely increased fatigue, heart rate, increased breathing, increased muscle tension, rapid speech with high volume, narrow perception, able to learn aunt not optimal, decreased concentration ability, selective attention and focused on stimuli that do not add anxiety, irritability, impatience, easy to forget, angry and crying; 3) High anxiety, individuals with severe anxiety tend to focus on something detailed and specific, and cannot think about anything else. The individual needs a lot of directions to focus his attention. Manifestations that arise at this level are complaining, dizziness, headache, nausea, insomnia, frequent urination, diarrhea, palpitations, perceptions narrowed, unable to learn effectively, focusing on oneself, and desire to eliminate high anxiety, feelings of helplessness, confusion and disorientation; 4) Panic deals with shock, fear, and terror because of control. Individuals with panic are characterized by already breathing, pupil dilatation, palpitations, pale, diaphoresis, incoherent speech, unable to respond to simple commands, shouting, screaming, hallucinations and delusions. 


\section{SEFT (Spiritual Emotional Freedom Technique)}

SEFT is a relaxation technique using the combination of body systems and spiritual therapy techniques by pressing at certain points on the body (Rofacky \& Aini, 2015). SEFT is a therapy that uses a combination of spiritual power and energy psychology (Verasari, 2014). According to Zainudin in (Verasari, 2014), SEFT is not developed to solve physical or emotional problems, but there are four types, namely: (1) SEFT for healing, to achieve maximum physical and psychical health and healing; (2) SEFT for success, to achieve whatever the individual personally wants; (3) SEFT for happiness, to achieve happiness; and (4) SEFT for individual greatness, to form a good and right person and not cause negative impact on the environment. The use of SEFT techniques from various findings given to individuals in various fields can reduce stress, depression and anxiety (Bakara, Ibrahim, \& Sriati, 2013).

\section{Steps for Using the SEFT Technique}

According to (Wirawan, 2007) explained that the uses of SEFT techniques are:

\section{The Set-Up}

At this stage, there will be two types of set up: 1) The set-up belief/set-up, a belief that aims to solidify our steps (individuals can use existing beliefs or add new beliefs and replace old beliefs). For example: the individual chooses not to worry about expressing his or her opinion. Then examples of beliefs that can be instilled into the individual are: to express opinions in front of the class is a positive thing, daring to express opinions in front of the class will show to other friends that we understand what is being learned, "I believe can express opinions in front of the class," etc; 2) The set-up words (prayer and resignation) aims to transfer spiritual energy into the individual body, directing energy to appropriate advice, overcoming psychological reversal (psychological resistance). For example, I cannot express opinions. I cannot understand the material. I cannot possibly argue in front of the class and so on. If the negative beliefs or thoughts like the above examples occur, then the set up, words that can be pronounced are: Oh God even though my hands are trembling to argue, but I choose to argue in front of the class, make it easier Oh God because only you are the Giver of Science.

\section{Tapping}

Tapping is light taps with two fingertips at certain points on our body as much as approximately seven times while continuing tune-in. These points are the tip of "The Major Energy Meridians" which if we tap a few times will have an impact on the neutralization of emotional distress or pain that we feel. This is because the body's energy flow runs normally and returns to balancing. Here are the Fats points we need to tap: side thumb, side finger, middle finger, side pinkie, karate chops, inner wrist, an outer wrist in the middle of the pinkie bone and sweet. Tapping done at these points is done repeatedly

\section{Nine Gamut Procedure}

This technique is nine movements to stimulate the brain. Any movement (which might be considered strange) to stimulate a particular brain part. These nine movements are done while tapping on one of the energy points on the body called the gamut spot. The nine movements of the gamut of the procedure are, closing the eyes (firmly), opening the eyes (bulging), eyes moved strongly to the bottom right (silent head), eyes moved strongly to the lower left (silent head), turning the eye clockwise, twisting the counter clockwise, mumbling (hm hm $\mathrm{hm}$ ) for two seconds, night 1,2,3,4,5 in rhythm, mumbling like a seven.

\section{The Tapping Again}

After completing the nine gamut procedure, the final step is to repeat the tapping and end with a long breath, and blow it out (coupled with Thanksgiving).

\section{Conclusions}

The use of SEFT technique can decrease the level of counselee anxiety, whereas before being given SEFT treatment the anxiety level of counselee is in the weight category. After being treated using SEFT the anxiety level of counselee becomes light and normal. It thus explains that the SEFT technique can be used to decrease an anxiety level of the counselee.

\section{References}

Anak Takom, L., Bullare, F., \& Nawi, N. H. M. (2016). Campuran Kebimbangan Dan Kemurungan Dalam Kalangan Ibu Bapa Kanak-Kanak Kurang Upaya Fizikal Di Luar Bandar Sabah (Mixture Of Anxiety And Depression Among Parents Of Physical Disabled Children In Rural Sabah). Jurnal Psikologi Malaysia, 30(2).

Ardtiyani, M. F. (2014). Penyuluhanspiritual Emotional Freedom Technique (Seft) Sebagai Solusi Kesehatan 
Pada Wargadusun Babadan, Selomirah, Ngablak, Magelang, Jawa Tengah. Asian Journal of Innovation and Entrepreneurship, 3(3), 201-205.

Astuti, E. S. (2010). Bahan Dasar Untuk Pelayanan Konseling Pada Satuan Pendidikan Menengah Jilid I. Jakarta: PT Grasindo.

Aulianita, Y., \& Sudarmiati, S. (2015). Pengaruh Spiritual Emotional Freedom Technique Terhadap Kecemasan Wanita Klimakterium Di Rw 6 Kelurahan Pedalangan Kecamatan Banyumanik Kota Semarang Jawa Tengah.

Bakara, D. M., Ibrahim, K., \& Sriati, A. (2013). Pengaruh Spiritual Emotional Freedom Technique (SEFT) terhadap Tingkat Gejala Depresi, Kecemasan, dan Stres pada Pasien Sindrom Koroner Akut (SKA) Non Percutaneous Coronary Intervention (PCI). Abstrak.

Barlow, D. H. (2002). Anxiety and Its Disorders.

Budiantoro, W. (2015). Kecemasan Penyair Abdul Wachid Bs Dalam Perspektif Psikoanalisis Sigmund Freud. IAIN Purwokerto.

Creswell, J. W. (2013). Research design: Qualitative, quantitative, and mixed methods approaches: Sage publications.

H. O. Shaibu; J. E., Imhonde; Handayani, Lina, I. H. (2012). Type of Birth, Depression and Anxiety as determinates of Breastfeeding Attitude among Nursing Mothers. International Journal of Public Health Science (IJPHS), (Vol 1, No 2: December 2012), 49-54. Retrieved from http://www.iaesjournal.com/online/index.php/IJPHS/article/view/1253

Hazlett-Stevens, H. (2008). Psychological approaches to generalized anxiety disorder: A clinician's guide to assessment and treatment. Springer Science \& Business Media.

Juliantine, T. (2012). Profil Tentang Anxiety Pada Atlet Tenis. Universitas Pendidikan Indonesia, XXXIII(2), 8187. https://doi.org/10.1007/s13398-014-0173-7.2

Juneman Wahyu; Setiani, Yeni, J. R. (2013). Computer Anxiety, Academic Stress, and Academic Procrastination on College Students. Journal of Education and Learning, (Vol 7, No 3: August 2013), 147152. Retrieved from http://journal.uad.ac.id/index.php/EduLearn/article/view/878

Kearney, C. (2006). Social anxiety and social phobia in youth: Characteristics, assessment, and psychological treatment. Springer Science \& Business Media.

Kuraesin, N. D. (2009). Faktor-faktor Yang Mempengaruhi Tingkat Kecemasan Pasien Yang Akan Menghadapi Operasi Di RSUP Fatmawati. Universitas Islam Negeri Syarif Hidayatullah Jakarta, 61-88.

Luciani, J. J. (2002). Self-coaching: How to heal anxiety and depression. John Wiley \& Sons.

Maturidi, A. D. (2014). Metode Penelitian Teknik Informatika: Deepublish.

MOHAMAD, D. (2014). AL-HIKMAH. Jurnal Al-Hikmah, 6, 94-106.

Muarifah, A. (2012). Hubungan kecemasan dan agresivitas. HUMANITAS (Jurnal Psikologi Indonesia), 2(2), $102-112$.

Mulyo, B. H. (2007). Bimbingan Dan Konseling: Seft Sebagai Model Terapi. Jurnal Ilmu Dakwah, vol 15,2 (2007): Jurnal Ilmu Dakwah).

P Andri, Y. D. A. (2007). Anxiety Theory Based On Classic Psychoanalitic and Types of Defense Mechanism To Anxiety. Journal of the Indonesian Medical Association, (Vol. 57 No. 7 July 2007). Retrieved from http://indonesia.digitaljournals.org/index.php/idnmed/article/view/758

Padmadewi, N. N. (1998). Students Anxiety in Speaking Class and Ways of Minimising It. Jurnal Ilmu Pendidikan, (Vol $\quad 5 \quad$ (1998): $\quad$ Edisi $\quad$ Khusus). $\quad$ Retrieved from http://journal.um.ac.id/index.php/jip/article/view/1062

Prabowo, P. S., \& Sihombing, J. P. T. (2012). Gambaran Gangguan Kecemasan pada Mahasiswa Fakultas Kedokteran Universitas "X" Angkatan 2007. Jurnal Kedokteran Maranatha, 9(2), pp-162.

Ramaiah, S. (2003). Kecemasan, bagaimana mengatasi penyebabnya: Yayasan Obor Indonesia.

Rofacky, H. F., \& Aini, F. (2015). Pengaruh Terapi Spiritual Emotional Freedom Technique (SEFT) terhadap Tekanan Darah Penderita Hipertensi. Jurnal Keperawatan Soedirman, 10(1), 41-52.

Saari, C. Z. (2015). Penyakit Gelisah (Anxiety/Al-Halu') Dalam Masyarakat Islam Dan Penyelesaiannya Menurut Psiko-Spiritual Islam. Jurnal Usuluddin, 14(14).

Sanders, D., \& Wills, F. (2002). Counselling for Anxiety Problems. Sage.

Sari Oktaviani Desmawati; Ardi, Havid, F. R. (2013). An Analysis Of Students' English Language Anxiety At Sman 7 Padang. Journal of English Language Teaching, (Vol 1, No 3 (2013): Serie A), 51-60. Retrieved from http://ejournal.unp.ac.id/index.php/jelt/article/view/2367

- Shobirun; -, Arwani, N.-. (2011). The Difference of Anxiety Level on Hemodyalisis Patient Applied Health Education Using Leaflet and Audiovisual Aids. PROSIDING SEMINAR NASIONAL, (2011: PROSEDING SEMINAR NASIONAL KEPERAWATAN PPNI JATENG). Retrieved from http://jurnal.unimus.ac.id/index.php/psn12012010/article/view/333

Setiawan, S. D. (2015). The Effect of Chemotherapy in Cancer Patient to Anxiety. Jurnal Majority, 4(4), 94-99. Taufiq, M. I. (2007). Panduan Lengkap dan Praktis Psikologi Islam: Gema Insani. 
Verasari, M. (2014). Efektivitas Terapi Spritual Emotion Freedom Technique (SEFT) terhadap Penurunan Insomnia pada Remaja Sebagai Residen Napza. Jurnal SosioHumaniora, 5(1).

Wirawan, B. (2007). Stop Smoking Revolution; metode termudah dan terampuh berhenti merokok dengan metode B-seft dan NLP: Hikmah. Jakarta.

Yudha, B. P. (n.d.). Hubungan Antara Persiapan Belajar Dengan Kecemasan Dalam Menghadapi Ujian Pada Siswa Di Sman Xxx Padang. Psyche 165 Journal, 5(1), 23-26.

Yunita, E., Darminto, E., \& Si, M. (2013). Penerapan Spiritual Emotional Freedom Technique Dalam Bimbingan Kelompok Untuk Menurunkan Kecemasan Siswa SMA Dalam Menghadapi Ujian Nasional. Jurnal BK Unesa, 3(1). 